Biosimilars for Healthcare Professionals For personal use only. Not to be reproduced without permission of the publisher (editorial@gabi-journal.net).

\section{Biosimilars: achieving long-term savings and competitive markets}

\author{
Jorge Mestre-Ferrandiz, PhD; Adrian Towse, MA; Mikel Berdud, PhD
}

Payers need to think strategically in medium/long term to maximize benefits from biosimilars. Concerns about biosimilars' interchangeability/substitution (with their reference product) and uncertainty about outcomes act as barriers for their uptake. This paper recommends a policy which provides: (1) incentives for budget holders to use safe and effective lower-cost products; (2) market support to collect real world outcomes evidence to increase prescribers' confidence in biosimilars.

Keywords: Biosimilars, competition, incentives, real world outcomes, savings, value for money

\begin{abstract}
Introduction
As biosimilars begin to increase their share in the market, it is critical for payers to adopt strategic approaches to: (1) ensure a competitive and sustainable biosimilars market; (2) achieve value for money from their use. Here we propose a strategic approach we think could achieve both goals. This commentary is based on recent research published by the authors [1] Another recent report asserts that 'a functioning competitive (biosimilars) market is therefore needed to deliver sustainability for payers, physicians and manufacturers alike' [2], which is complementary to our proposal.
\end{abstract}

\section{Payer savings at stake \\ Over the past several years, biologicals have gained significant traction in the pharma- ceutical industry, representing more than US $\$ 150$ billion in global sales in 2013. By 2020 they are predicted to generate US\$290 billion in revenue and comprise $27 \%$ of the pharmaceutical market [3]. Forty-eight per cent of biologicals sales come from 11 bio- logicals that face loss of exclusivity over the next seven years [3]. This, along with the increasing worldwide focus on improving healthcare access and the cost of care, pres- ents an attractive opportunity for biosimilars manufacturers and third-party payers. How- ever, necessary incentives need to be put in place to reap the benefits from biosimilars in the medium and long term.}

Aitken shows a range of estimates of biosimilar savings potential in the EU5 and the US, for eight key products in 2015-2020 [2]. A key driver of these savings will be the level of price discount offered by biosimilars; for a $40 \%$ discount, savings can be nearly Euros 100 billion. With a 20\% discount, savings are halved. Biosimilar medicines have the potential to enter markets by 2020 for a number of key biologicals. Aitken notes the extent of the actual savings realized - where payers end up on this spectrum - is dependent on policy development and implementation across all stakeholders in the healthcare system' [2]. He also shows the great disparities on current biosimilars price discounts across countries and molecules; from a maximum 55\% price discount in Germany for epoetin, to a small (1\%) price increase in Spain for granulocyte colonystimulating factors (G-CSFs). Different pricing and reimbursement methods apply differently across therapy areas and countries [1]. However, across the European Union, the use of erythropoietins (EPOs), G-CSFs and human growth hormone (HGH) have all increased following the launch of biosimilar versions [2].

\section{Recent developments in the US and Europe}

The US Food and Drug Administration (FDA) approved in April 2016 a second biosimilar product - Inflectra (Infliximab-dyyb), a biosimilar to Remicade (infliximab) - and expects to approve other biosimilars in the future. FDA has approved Inflectra for the same indications as Remicade, i.e. ankylosing spondylitis, Crohn's disease, paediatric Crohn's disease, psoriasis, psoriatic arthritis, rheumatoid arthritis and ulcerative colitis. Inflectra is the first biosimilar monoclonal antibody (mAb) medication to receive approval in the US. It is manufactured by the Korean firm Celltrion and will be marketed and sold by Pfizer [4]. FDA has also designated a placeholder non-proprietary name for Inflectra - infliximab-dyyb, as it did for the first biosimilar approved in the US in March 2015, Zarxio (filgrastim-sndz; reference product Neupogen [filgrastim]). The agency has, however, made it clear that it has not yet made a final decision on whether biosimilars will receive the same International Nonproprietary Name (INN) as their reference biologicals or unique names [5].

It has been argued it may be years before Inflectra reaches US pharmacies - for two main reasons: (1) patent litigation; (2) reservations due to a lack of clarity around 'interchangeability' [4, 6].

On (1), the Biologics Price Competition and Innovation Act (BPCI Act), which was part of the Patient Protection and Affordable Care Act signed by President Barack Obama in March 2010, created a process by which FDA could approve products considered biosimilar - and included a procedure known as the 'patent dance' whereby once the application for approval has been submitted to FDA, a negotiation takes place between the biosimilar sponsor and the reference product sponsor. The biosimilar sponsor provides their application and relevant information about manufacturing, and the reference product sponsor then can respond with any patent or other concerns [4]. As shown in the two cases to date, this can delay the introduction of the biosimilar.

On (2), there seems to be some confusion around the 'interchangeability' issue [6] although the drug's sponsor neither sought interchangeability designation, nor was it approved as being interchangeable [4]. Without that designation, pharmacies cannot substitute the biosimilar in a prescription written for the original drug. But insurers could give the biosimilar agent a preferred position in their formularies and refuse to cover the full cost of the original product [4]. 
In Europe, the second biosimilar antitumour necrosis factor (TNF) was approved by the European Medicines Agency (EMA) on 14 January 2016: Benepali (SB4) with reference medicine Enbrel (etanercept). Benepali is produced by Samsung Bioepis, which is a joint venture between South Korean electronics giant Samsung and biotechnology company Biogen [7]. EMA had already approved in 2013 two infliximab biosimilars produced by Celltrion (Remsima and Inflectra; reference product Remicade) which are in fact the same mAb. Celltrion markets Remsima and Hospira markets Inflectra. Pfizer acquired Hospira in September 2015, and thus it currently markets Inflectra. EMA Committee for Medicinal Products for Human Use (CHMP) announced on 1 April 2016 that it had recommended granting the marketing authorization for the second biosimilar infliximab product - reference product is Remicade. The biosimilar infliximab, which will be called Flixabi (SB2), is also produced by Samsung Bioepis.

\section{Biosimilars are not generics}

Economic theory suggests five reasons for why we should not expect similar levels of price discounting for biosimilars in comparison with chemical generics [1]. First, the investment needed to develop and market a biosimilar is considerably higher than the US\$1 million to US\$5 million that is required to enter the generics market. It takes seven to eight years to develop a biosimilar, at a cost of between US $\$ 100$ million and US\$250 million [8]. Second, the complexity of mAbs makes their development and manufacturing costs much higher compared to the nonmAb biosimilars - many blockbuster mAbs are approaching their patent expiration date and biosimilar competition from new entrants is expected [9].

Third, there is no (automatic) interchangeability (or substitution at pharmacy level) of the biosimilar with the reference product. The only exception is France although only for a patient beginning a course of treatment; substitution cannot be made partway through a course. For instance, the American College of Rheumatology (ACR) issued a statement on biosimilars in 2015, indicating the ACR 'does not endorse switching stable patients to a different medication (including a biosimilar) of the same class for cost saving reasons without advance express consent from the prescribing provider and knowledge of the patient' [10]. This means manufacturers need to communicate with prescribers for reassurance and promotion of brand name. Originators have established relationships with prescribers. Substantial investment is required by biosimilar-only manufacturers to replicate such relationships. Fourth, postlaunch studies may be necessary to address concerns about comparability, which raises entry costs. And fifth, given these entry costs, there will be fewer biosimilar entrants and hence less price competition [11-13].

\section{Extrapolation}

EMA states that 'if biosimilarity has been demonstrated in one indication, extrapolation to other indications of the reference product could be acceptable with appropriate scientific justification' [14]. The issue of extrapolation is a topic of great interest. EMA has backed up its position with evidence from post-marketing authorization [15]. In the US, FDA approved Inflectra for the same indications as Remicade. In Europe, Benepali was approved for all the adult indications for which Enbrel is approved, namely rheumatoid arthritis, axial spondyloarthritis, psoriatic arthritis and plaque psoriasis. However, unlike Enbrel, Benepali is not approved for juvenile idiopathic arthritis or paediatric plaque psoriasis. This is due to Benepali only being available in presentations (singleuse pre-filled syringe and pre-filled pen) that contain $50 \mathrm{mg}$ etanercept per dose [8].

\section{Strategic options}

Broadly speaking, there can be two types of economic regulation for biosimilars (and indeed for health technologies): controlling prices or supporting market forces. The former includes direct price interventions such as reference pricing or tendering, while the latter relates to market support such as investing in infrastructure for measuring and monitoring outcomes, facilitating pharmacovigilance and collecting real world evidence. These can increase prescribers' confidence in biosimilars. In addition, incentives directed towards the 'demand' side will be important. These include options targeting pharmacists (such as allowing, or not, substitution between the reference product and the biosimilar, and between biosimilars) and prescribers (such as prescribing quotas).

To maximize the benefits from biosimilars, we recommend a policy which provides:

1. Incentives for budget holders to use lower-cost products when these are safe and effective, and so provide better value for money.

2. Market support, collecting real world outcomes evidence, creating greater willingness on the part of budget holders and clinicians to seek value for money by using biosimilars and originator products interchangeably. Moreover, there might be greater uncertainty and reluctance (increasing entry barriers) to prescribe biosimilars for those extrapolated indications. There is likely to be a greater need for post-launch observational data for such indications.

These options can enable policymakers to take a more strategic approach, which would provide and incentivize the collection and use of high quality outcomes data.

Competing interests: The Office of Health Economics receives a programme research grant from the Association of the British Pharmaceutical Industry. No separate funding was received for this paper. Dr Jorge Mestre-Ferrandiz, Mr Adrian Towse and Dr Mikel Berdud are all employees of the Office of Health Economics. Dr Jorge Mestre-Ferrandiz and $\mathrm{Mr}$ Adrian Towse, as part of the Office of Health Economics, received a research grant from Amgen to run a workshop on biosimilars and health technology assessment, and have previously received consulting funding from both innovator and biosimilar companies.

Provenance and peer review: Commissioned; externally peer reviewed.

\section{Co-authors}

Adrian Towse, MA

Mikel Berdud, PhD

Office of Health Economics, 7/F, 105 Victoria Street, London SW1E 6QT, UK

\section{References}

1. Mestre-Ferrandiz J, Towse A, Berdud M. Biosimilars: how can payers get long-term savings? Pharmacoeconomics. 2016;34(6):609-16.

2. Aitken M. Delivering on the potential of biosimilar medicines. The role of functioning competitive markets. 2016. IMS Institute for Healthcare Informatics.

3. Jacoby R, Smith E, Wilkins D, Iyer D, Peltre S. 2015. Winning with biosimilars. Opportunities in global markets. Deloitte Development LLC.

4. Walsh N. FDA approves infliximab biosimilar, Inflectra - can be used for arthritis, psoriasis, and inflammatory bowel disease. 5 April 2016. MedPageToday.

References 5 to 15 can be found on page 130 . 


\section{Biosimilars: achieving long-term savings and competitive markets References (please see the full manuscript on page 103)}

5. GaBI Online - Generics and Biosimilars Initiative. FDA approves infliximab biosimilar Inflectra aplasia [www.gabionline.net]. Mol, Belgium: Pro Pharma Communications International; [cited 2016 Aug 31]. Available from: www.gabionline. net/Biosimilars/News/FDA-approves-infliximabbiosimilar-Inflectra

6. GaBI Online-Generics and Biosimilars Initiative. Thimmaraju PK, Rakshambikai R, Farista R, Karthaveerya J. Legislations on biosimilar interchangeability in the US and EU - developments far from visibility [www.gabionline.net]. Mol, Belgium: Pro Pharma Communications International; [cited 2016 Aug 31]. Available from: www. gabionline.net/Sponsored-Articles/Legislationson-biosimilar-interchangeability-in-the-US-andEU-developments-far-from-visibility

7. GaBI Online - Generics and Biosimilars Initiative. EMA recommends approval of etanercept biosimilar [www.gabionline.net]. Mol, Belgium: Pro Pharma Communications International; [cited 2016 Aug 31]. Available from: www.gabionline.net/Biosimilars/ News/EMA-recommends-approval-of-etanerceptbiosimilar

8. Malik A. 2016. Samsung Bioepsis scores EMA approval for Benepali, the first Etanercept biosimilar to be approved in Europe. Decision Resources Group. Drug Watch. 28 January 2016.

9. Udpa N, Million RP. Monoclonal antibody biosimilars. Nat Rev Drug Discov. 2016;15(1): $13-4$.

10. The American College of Rheumatology. Position Statement. Biosimilars. [cited 2016 Aug 31]. Available from: http://www.rheumatology. org/Portals/0/Files/Biosimilars.pdf

11. Grabowski H, Kyle M. Generic competition and market exclusivity periods in pharmaceuticals. Manag Decis Econ. 2007;28(4-5):491-502.
12. Reiffen D, Ward M. Generic drug industry dynamics. Rev Econ Stat. 2005;87(1):37-49.

13. Saha A, Grabowski H, Birnbaum H, Greenberg P, Bizan O. Generic competition in the US pharmaceutical industry. Int $\mathrm{J}$ Econ Bus. 2006; 13(1):15-38

14. European Medicines Agency. Guideline on similar biological medicinal products. CHMP/437/04 Rev 1. 23 October 2014 [homepage on the Internet]. [cited 2016 Aug 31]. Available from: http://www.ema.europa.eu/docs/en_GB/ document_library/Scientific_guideline/2014/10/ WC500176768.pdf

15. Derbyshire M. Top developments in biosimilars during 2015. Generics and Biosimilars Initiative Journal (GaBI Journal). 2016;5(1):42-4. doi:10.5639/gabij.2016.0501.010

DOI: 10.5639/gabij.2016.0503.027

Copyright (c) 2016 Pro Pharma Communications International 